\title{
珪燐酸カルシゥムガラスおよび珪燐酸マグネシウム ガラスのニ，三の性質
}

\author{
金沢孝文・川副博司・池田正義
}

(東京都立大学工学部工業化学教室)

\section{Some Properties of Calcium Silicophosphate Glasses and Magnesium Silicophosphate Glasses}

By

Takafumi KANAZAWA, Hiroshi KAWAZOE and Masayoshi IKEDA

$\left(\begin{array}{l}\text { Department of Industrial Chemistry, Faculty of Technology, } \\ \text { Tokyo Metropolitan University; Tokyo }\end{array}\right)$

Some physical and chemical properties of glasses in the systems $\mathrm{CaO}-\mathrm{P}_{2} \mathrm{O}_{5}-\mathrm{SiO}_{2}$ and $\mathrm{MgO}-\mathrm{P}_{2} \mathrm{O}_{5}-\mathrm{SiO}_{2}$ have been measured. The glass samples were prepared to have the compositions ranging from 0.7 to 1.7 in mole ratio $\mathrm{RO} / \mathrm{P}_{2} \mathrm{O}_{5}(\mathrm{RO}=\mathrm{CaO}, \mathrm{MgO})$ and from 0 to 1.1 in mole ratio $\mathrm{SiO}_{2} / \mathrm{P}_{2} \mathrm{O}_{5}$.

In the composition range with high $\mathrm{SiO}_{2}$ content, the glass-forming region in the system $\mathrm{MgO}-\mathrm{P}_{2} \mathrm{O}_{5}-\mathrm{SiO}_{2}$ was found to be more extended than that in the system $\mathrm{CaO}-\mathrm{P}_{2} \mathrm{O}_{5}-\mathrm{SiO}_{2}$.

Density and refractive index of these samples decreased with increasing $\mathrm{SiO}_{2}$ content. The anomalies were found on the physical properties, i.e. density and refractive index, of the glasses in the system $\mathrm{MgO}-\mathrm{P}_{2} \mathrm{O}_{5}-\mathrm{SiO}_{2}$ at a composition corresponding to about 1 in mole ratio $\mathrm{MgO} / \mathrm{P}_{2} \mathrm{O}_{5}$, similar to those of the glasses in the system $\mathrm{MgO}-\mathrm{P}_{2} \mathrm{O}_{5}$ which had been reported by other investigators.

Solubility tests for the silicophosphate glasses with various solvents, especially, acid solvents such as hydrochloric acid and citric acid solutions, resulted in the considerably high solubilities of $\mathrm{P}_{2} \mathrm{O}_{5}$ component as compared with the solubilities of the corresponding phosphate glasses for the same solvents.

As the forms of the phosphate ions existing in the $\mathrm{CaO}-\mathrm{P}_{2} \mathrm{O}_{5}-\mathrm{SiO}_{2}$ glass whose mole ratio $\mathrm{CaO} / \mathrm{P}_{2} \mathrm{O}_{5}$ is over 1 , pyro-, trimeta- and tetrameta-phosphate ions were detected by paper chromatography. It was confirmed that the crystals formed by heat-treatment of these glasses were neither silica nor silicate minerals but condensed phosphates without exception.

[Received June 6, 1969]

\section{1. 緒言}

著者らの一人 ${ }^{1)}$ は，さきに各種の珪燐酸塩ガラスを低 酸素型および高酸素型に分類しうることを示した. 組成 でいえば, 前者は比較的 $\mathrm{P}_{2} \mathrm{O}_{5}$ 含量が多く, 後者ではよ り $\mathrm{SiO}_{2}$ 含量が多い1). 本報で扱うアルカリ土類珠燐酸 塩ガラスについても,上の分け方を適用することにする. 以下 $\mathrm{RO}$ (アルカリ土類酸化物), $\mathrm{CaO}, \mathrm{MgO}, \mathrm{P}_{2} \mathrm{O}_{5}$, $\mathrm{SiO}_{2}$ の各成分あるいはそれらのモル量を，適宜それぞ れ R, C, M, P, S と略記する.

高酸素型のガラスは, 網目形成イオンに対する酸素比 が大きいために， $\mathrm{P}$ 原子のほとんどが独立 $\mathrm{PO}_{4}$ 四面体 を形成する，というような特殊の場合に成立する. CM-P-S 系の熔成苦土燐肥ガラスがその代表例と考えら
れる.この系のガラスの構造 ${ }^{1)}$, 燐酸イオンの形態 ${ }^{2}$, 諸 物性 ${ }^{3)}$ の詳細に関しては, すでに著者らにより明らかに された ${ }^{1)}$ ).

本稿は, 低酸素型 R-P-S 系ガラスの物性, 化学性の いくつかを報告するのが目的である. $\mathrm{R}$ としては $\mathrm{C}, \mathrm{M}$ の 2 種をえらんだ. 選択の理由は, $\mathrm{CP}, \mathrm{MP}$ 両ガラスの

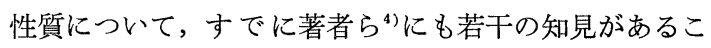
と, したがってそれらへの S 添加の影響の問題として RPS ガラスを考察しらること, さらに Kordes ${ }^{5)}$ の分類 によれば C-P, M-P 各系がそれぞれ normal なガラス, anomal なガラスをつくること, などに基づく. C, M を含む各珠燐酸塩ガラスを, 本文中では CPS, MPS と 略示する. 
低酸素型に属するアルカリあるいはアルカリ土類珪燐 酸塩ガラスの構造, 性質については, 数件の報告があ $ろ^{(6) \sim 10)}$. du Plessis ${ }^{6)}$ は S の導大により，ガラス質縮 合燐酸塩の重合度が低下すること，および $\mathrm{S}$ 量の増大 によってガラスの溶解性が大きくなることをみとめた。 高橋 ${ }^{7}$ はこれらのガラスの諸物性を測定し報告してい る.さらに大橋ら ${ }^{8}$ は, ガラス中には P-O-Si 結合が存 在し, 結晶中ではそれがみとめられないと考えられるこ とを述べた。高酸素型の珪燐酸塩ガラスに関しては，他

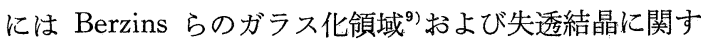
る研究 ${ }^{10)}$ がみられる程度である.

一般に珪燐酸塩ガラスのガラス化領域は未だ明瞭では ない. $\mathrm{Na}_{2} \mathrm{O}-\mathrm{P}_{2} \mathrm{O}_{5}-\mathrm{SiO}_{2}$ 系のガラス化組成範囲について 高橋 ${ }^{7}$ が触れている程度にすぎない.上述の高酸素型領 域と低酸素型領域との間にはっきりした境界があるか否 かも問題であって，未検討のままになっている，また， ガラス中における $\mathrm{P}, \mathrm{S}$ の構造的役割， $\mathrm{P}$ と $\mathrm{S}$ との構 造的関連性なども，今後解決したい事柄である. 既報 中での考察のさい, 低酸素型は [燐酸塩ガラス $+\mathrm{S}]$, 高 酸素型は [珪酸塩ガラス十燐酸塩] の構造を有すること を一応想定したのであったが，それについて明確な論義 をすすめるには，まず種々の構造化学的データの提示が 必要となろう．ことに CPS にくらべると MPS につい ての知見は非常に少なく, 全体的に R-P-S 系ガラスの 検討は今まで十分とは言えない. 本報は, CPS, MPS について, ガラス化組成範囲, 密度, 屈折率, 溶剤溶解 性，燐酸イオンの鎖長分布，失透結晶種などを明らかに し, 比較検討し, 構造化学的論議のための資料若干を得 たものである。

\section{2. 実験}

\section{1 試料}

先述のように，C-P-S， M-P-S 各系のガラス化の組 成領域が明らかでないので，まず， R-P 系において $\mathrm{R} / \mathrm{P}$ モル比一以下断わらない限りモル比を用いる——をそ れらのガラス化領域内で 3 通りにとり, これにおのおの $\mathrm{S}$ を加え, S/P の異なった試料多種をつくった.

原料は, 特級試薬の燐酸一水素カルシウム二水塩, 燐 酸一水素マグネシウム三水塩, 燐酸二水素アンモニウ ム, 光学ガラス用珪砂で, これらを表一1 に示した組成 になるように, 秤量混合した. 原料混合物を $500^{\circ} \sim 700$ ${ }^{\circ} \mathrm{C}$ で 3〜7 時間焼結したのち，炭化珪素発熱体坩堝型 電気炉を用いて熔融した。熔融用坩堝には CC印 SSA$\mathrm{H}$ を使用した. 熔融温度は C-P-S 系 : $1000^{\circ} \sim 1550^{\circ} \mathrm{C}$, M-P-S 系 : $1200^{\circ} \sim 1550^{\circ} \mathrm{C}$ で， $\mathrm{R}$ および $\mathrm{S}$ が多いほど 高温を必要とする. 融液は 2 枚のステンレス板間に流出 し, 急冷した.

得られた物質について，検鏡，X 線回折を行ない，
Table 1. Composition of glass samples.

\begin{tabular}{|c|c|c|c|c|c|}
\hline \multirow{3}{*}{ System } & \multirow{3}{*}{ Symbol } & \multicolumn{4}{|c|}{ Mole ratio } \\
\hline & & \multicolumn{2}{|c|}{ Theor. } & \multicolumn{2}{|c|}{ Obs. } \\
\hline & & $\mathrm{RO} / \mathrm{P}_{2} \mathrm{O}_{8}$ & $\mathrm{iO}_{2} / \mathrm{P}_{2} \mathrm{O}_{5}$ & $\mathrm{RO} / \mathrm{P}_{2} \mathrm{O}_{5}$ & $\mathrm{SiO}_{2} / \mathrm{P}_{2} \mathrm{O}_{5}$ \\
\hline \multirow{11}{*}{$\mathrm{CaO}-\mathrm{P}_{2} \mathrm{O}_{5}-\mathrm{SiO}_{2}$} & C 11 & $55 / 45$ & 0.286 & 1.20 & 0.22 \\
\hline & C 12 & " & 0.250 & & \\
\hline & C 13 & " & 0.200 & 1.27 & 0.19 \\
\hline & C 14 & " & 0 & 1.30 & 0 \\
\hline & C 21 & $50 / 50$ & 0.333 & & \\
\hline & C 22 & $"$ & 0.250 & 1.17 & 0.22 \\
\hline & C 23 & " & 0.200 & 1.17 & 0.16 \\
\hline & C 24 & " & 0 & 1.17 & 0 \\
\hline & C 31 & $40 / 60$ & 0.500 & 0.895 & 0.52 \\
\hline & C 32 & " & 0.333 & 0.826 & 0.34 \\
\hline & C 33 & " & 0.250 & 0.810 & 0.25 \\
\hline \multirow{14}{*}{$\mathrm{MgO}-\mathrm{P}_{2} \mathrm{O}_{5}-\mathrm{SiO}_{2}$} & C 34 & " & 0 & 0.853 & 0 \\
\hline & M 11 & $60 / 40$ & 0.400 & 1.66 & 0.41 \\
\hline & M 12 & " & 0.250 & 1.74 & 0.36 \\
\hline & M 13 & " & 0.200 & 1.66 & 0.21 \\
\hline & M 14 & " & 0 & 1.64 & 0 \\
\hline & M 21 & $50 / 50$ & 1.00 & & \\
\hline & M 22 & " & 0.500 & 1.21 & 0.47 \\
\hline & M 23 & " & 0.333 & 1.20 & 0.29 \\
\hline & M 24 & " & 0.312 & 1.18 & 0.21 \\
\hline & M 25 & $"$ & 0 & 1.12 & 0 \\
\hline & M 31 & $40 / 60$ & 1.00 & 0.899 & 1.1 \\
\hline & M 32 & " & 0.500 & 0.720 & 0.64 \\
\hline & M 33 & " & 0.250 & 0.811 & 0.30 \\
\hline & M 34 & $"$ & 0 & 0.982 & 0 \\
\hline
\end{tabular}

結晶の存否を判定した.その上で結晶の含まれていない ものについては組成をしらべた. 結果の一部は表一1 に 記してある. 各成分の分析法は, 燐酸 : バナドモリブデ ン酸法 ${ }^{11)}$, アルカリ土類 : ETA キレート滴定法 ${ }^{12)}$, 珪 酸 : 過塩素酸重量法 ${ }^{13}$ である. 分析の結果, 水分含量が 少量と思われるものについてのみ，以後の実験を行なっ た. 実験方法は以下に述べるが，測定方針や操作は，大 体既報节に準じている。

\section{2 密度・屈折率}

試料を所要粒度に粉砕し，五酸化燐デシケーター中で 乾燥後, 密度と屈折率を測定した. 密度の測定には, 200 メッシュ全通粉末をとり，ケロシンを浸液とし，ピ クノメーターを用いた。 屈折率は 100 メッシュ全通試料 について，アッべ屈折計により測定した.

\section{3 溶 解 性}

化学的性質を調べる一法として, ガラス中の燐酸分の 溶剤溶解性 ${ }^{4}$ を測定した。 100 メッシュ全通のガラス粉 末 $1 \mathrm{~g}$ に溶剤 $150 \mathrm{~m} l$ を加え, 天地回転式で 1 時間ふり まぜたのち燐酸分を定量 ${ }^{11}$ した。溶解率は溶解した燐酸 の全燐酸に対する割合で示す。測定に用いた溶媒は， 水, $\mathrm{N} / 2$ 塩酸, $2 \%$ クエン酸, $10 \%$ 中性クエン酸ナト リウム(クエン酸を少量の水にとかし，カセイソーダ溶 液で $\mathrm{pH} 7$ 亿調整し，水で希釈する)，10\% 塩化ナトリ ウム, $3 \%$ ETA(ETA $2 \mathrm{Na}$ 塩を少量の水にとかし，カ セイソーダ溶液で $\mathrm{pH} 7$ に調整し, 水で希釈する), 10 \% カセイソーダ, 10\% アンモニア水である. 
2.4 ペーパー・クロマトグラフィー

$\mathrm{S}$ を添加したことによる燐酸イオンの鎖長変化をしら ベるためにペーパー・クロマトグラフィーを行なった。 測定は, 200 メッシュ全通の粉末 $50 \mathrm{mg}$ を $20 \mathrm{ml}$ の 3 $\%$ ETA (2.3 参照) に溶解させ, Bernhart-Chess $\left.{ }^{14}\right)$ の $\mathrm{B}$ 液および $\mathrm{Ebel}^{15)}$ の塩基性液により $18^{\circ} \sim 22^{\circ} \mathrm{C}$ ある いは $5^{\circ} \mathrm{C} て ゙ 5 〜 14 ~$ 時間展開して行なった. 使用口紙： 東洋濾紙 No. $51 \mathrm{~A}$.

得られたクロマトグラムを, 同条件で別に展開した標 準試料（オルト酸性燐酸ナトリウムなど）のそれと比較 し，扔の扔ののイオンを定性し，存在割合を推定した。

\section{5 失透物の $\mathrm{X}$ 線回折}

100 メッシュ全通試料を高アルミナ質坩堝に入れ，所 定温度 (表一 3 参照) で一定時間保持したのち，灿中で 放冷した. 加熱はカンタル箱型電気炉によった. 加熱失 透物を X 線回折 $\left(\mathrm{CuK}_{\alpha}\right.$ 線) し, 生成結晶種を同定し た。

\section{3. 結果と考察}

\section{1 ガラス化領域}

C-P-S 系, M-P-S 系のガラス化領域の一部を図-1 に示した. しらべた R/P 值の範囲は, C-P-S 系では $1.3 \geqq \mathrm{R} / \mathrm{P} \geqq 0.7, \mathrm{M}-\mathrm{P}-\mathrm{S}$ 系では $1.7 \geqq \mathrm{R} / \mathrm{P} \geqq 0.7$ で ある.ガラス化領域は，ガラスの製造条件に依存するも のであるから，それだけを独立させて論議することは困 難である.ここに示した值は, むろん概略のもので, 試 料数 $10 \mathrm{~g}$ を熔融後，金属ブロックにより急冷してガラ スが得られる組成，の意味とする.

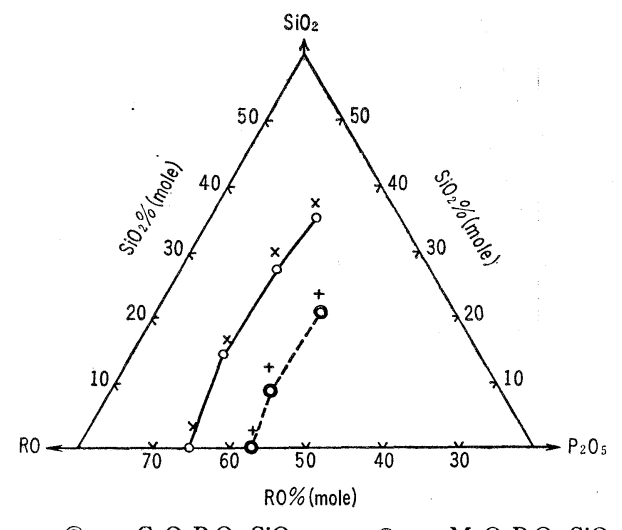

……... CaO $-\mathrm{P}_{2} \mathrm{O}_{5}-\mathrm{SiO}_{2}$,

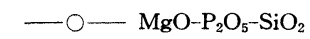

Fig. 1. Glass formation range locally indicated in the ternary systems of $\mathrm{CaO}-\mathrm{P}_{2} \mathrm{O}_{5}-\mathrm{SiO}_{2}$ and $\mathrm{MgO}-$ $\mathrm{P}_{2} \mathrm{O}_{5}-\mathrm{SiO}_{2}$.

図一1 からみとめられるよらに, S の導入に対する系 のガラス化範囲は， R/P 值とは無関倸に，M-P-S 系の 方が C-P-S 系よりつ齐に大であった。ささら 2 つの系 とも， R/P が小さくなるにつれて， $\mathrm{S}$ の導入量に対する ガラス化限界が高くなることがわかった。しかしガラス
中の $\mathrm{R}$ と $\mathrm{S}$ との量的関係は, 本実験での $\mathrm{R} / \mathrm{P}$ の範囲 では $\mathrm{R} \geqq \mathrm{S}$ である.すなわちモル量で考えるばあい, 珪酸はアルカリ土類より多量にガラス中に含まれること はない，ガラス化限界を越した組成の試料では，珪酸末 融解物の残留あるいは燐酸塩結晶の生成がみられた，後 者は短鎖燐酸イオンから成る憐酸塩であることを, X 線的に確認した。

\section{2 密度・屈折率}

CPS, MPS 両ガラスの密度および屈折率のおのおの に対する S の影響を図一2 および図一4にそれぞれ示 した. 図一 3 では M-P-S 系の值を $\mathrm{R} / \mathrm{P}$ に対してプロ ットした. 図一2，4 をみると双方の系の密度, 屈折率 は S の導大゚量を増すとともに減少している.このこと の意味を下に考察してみる。

ガラス中に含まれる珠酸分自体は後述 (3.4) するよう に縮合したかたちで情存在せず，P-O-Si-O-P 結合を つくっているものと推定される. このことは，大橋ら ${ }^{8}$ により珪燐酸ナトリウムガラスについて，指摘された。

それゆえ Sによってポリ燐酸イオンは切断された形式 になる。しかし本実験中で，S の添加により融液の粘性

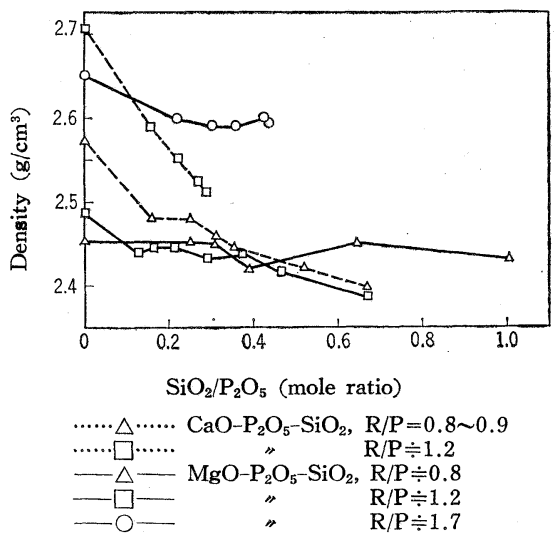

Fig. 2. Relation between density and $\mathrm{SiO}_{2} / \mathrm{P}_{2} \mathrm{O}_{5}$ mole ratio of the glass in the systems of $\mathrm{CaO}-\mathrm{P}_{2} \mathrm{O}_{5}-$ $\mathrm{SiO}_{2}$ and $\mathrm{MgO}-\mathrm{P}_{2} \mathrm{O}_{5}-\mathrm{SiO}_{2}$.

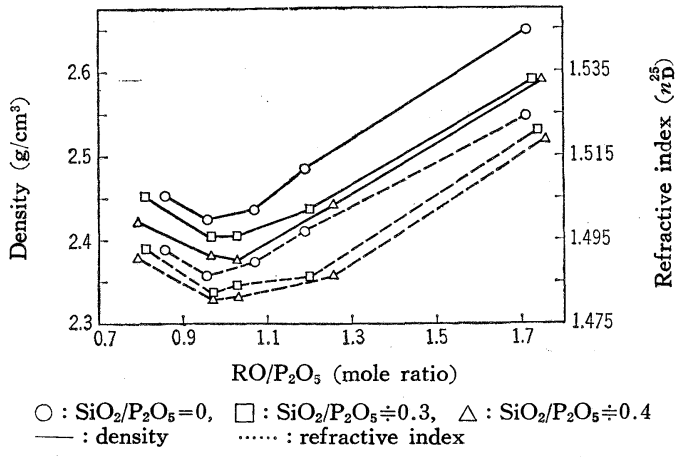

Fig. 3. Composition dependence of density and refractive index of the glass in the system $\mathrm{MgO}-\mathrm{P}_{2} \mathrm{O}_{5}-\mathrm{SiO}_{2}$. 


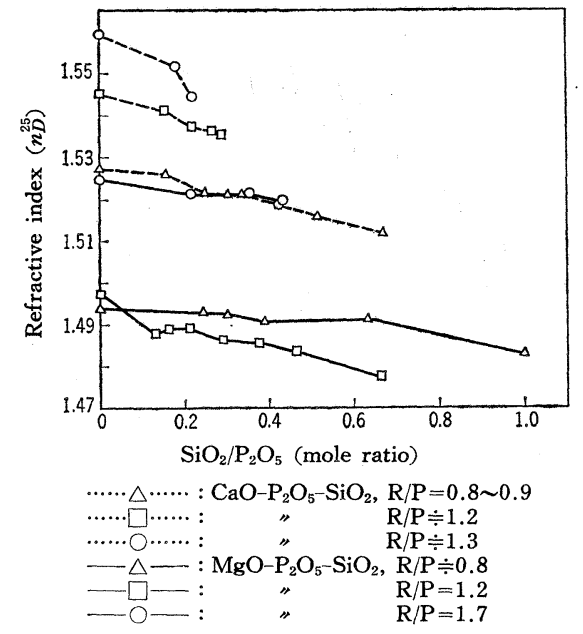

Fig. 4. Relation between refractive index and $\mathrm{SiO}_{2} /$ $\mathrm{P}_{2} \mathrm{O}_{5}$ mole ratio of the glass in the systems of $\mathrm{CaO}-\mathrm{P}_{2} \mathrm{O}_{5}-\mathrm{SiO}_{2}$ and $\mathrm{MgO}-\mathrm{P}_{2} \mathrm{O}_{5}-\mathrm{SiO}_{2}$.

が急激に増大することが一方でみとめられた．この現象

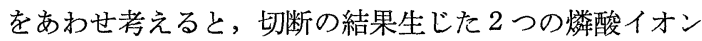
は，なお Si によってともかく結合されていると考えら れる．そこでこのガラスは，燐酸イオンと珪酸イオンと が混和した形式をもつ，すなわち構造的実質はともかく として, 形式的には [燐酸塩ガラス十珪酸塩ガラス］と みてもよい，ところが珪酸塩ガラスは，対応する燐酸塩 のそれにくらべて，小さな密度，屈折率をもつことが知 られている. 図一2，図一4の測定で S を加えたことは， 珪酸塩ガラスの添加割合を多くしたことに相当し，した がって全体として密度, 屈折率の減少がおこると解釈で きるであろう。なお C-P-S 系は, M-P-S 系にくらべ てもともとイオンがより密充填的であるために，空隌性 を加味するべき $\mathrm{S}$ の影響がより顕著にあらわれ，これ らの值の急激な減少を示すのであろう.

図-3 で $\mathrm{M}-\mathrm{P}-\mathrm{S}$ 系の $\mathrm{S} / \mathrm{P}=0$ の場合と $\mathrm{S}$ を含んだ ものとを比較すると, $\mathrm{S}$ を加えたとき $\mathrm{R} / \mathrm{P}$ 值が 1.0 1.3 ぐらいの範囲で密度, 屈折率の上昇がゆるやかであ ること一図一 2 , 図一 4 では $\mathrm{M}-\mathrm{P}-\mathrm{S}$ 系の $\mathrm{R} / \mathrm{P}=0.8$ と 1.2 の場合の曲線が $\mathrm{S} / \mathrm{P}=0.05 \sim 0.1$ で交叉してい ることでそれはみとめられる——除くと，0.7<R/P $<1.7$ の範囲で, 曲線の推移はほぼ同じである.すなわ ち $\mathrm{M}-\mathrm{P}$ 系で $\mathrm{R} / \mathrm{P}=1$ でみられる anomaly $\mathrm{y}^{5), 7), 16), 17) ~ か ゙, ~}$
M-P-S 系でも存在し, そのときの $\mathrm{R} / \mathrm{P}$ 值が 1 付近で あることも変りない．したがって M-P-S 系で M/P< 1 に㧍ける密度, 屈折率におよぼす $\mathrm{M}$ の影響は, M-P 系に括けると同様で， $\mathrm{S}$ が共存しても大きくは変化しな いと考えられる.

この事実に対しては，つぎのような解釈を与えうると 考える. $\mathrm{R}-\mathrm{P}$ 系に $\mathrm{R} / \mathrm{P} \leqq 1$ なる範囲で $\mathrm{M}$ と $\mathrm{S}$ とを 加えると, $\mathrm{M}$ と燐酸イオン中の分岐点をもつ箅所の $\mathrm{PO}_{4}$ 四面体とが，まず反応して，燐酸イオンの鎖状部分が生 じる. そしてこの傾向は $\mathrm{R} / \mathrm{P}=1$ まで続く.このとき共 存する $\mathrm{S}$ は， M の反応の結果生じた分岐点をもたない $\mathrm{PO}_{4}$ 四面体とのみ作用する．したがって分岐をもつ全て の $\mathrm{PO}_{4}$ 群が $\mathrm{M}$ との反応によって消費されるまで, す なわち metaphosphate の組成 $(\mathrm{R} / \mathrm{P}=1)$ まで, 密度, 屈折率の減少は持続する. $\mathrm{R} / \mathrm{P}=1$ 以上に導入された $\mathrm{M}$ は短鎖の燐酸イオンを生成させ, 密度, 屈折率の上昇を もたらす．しかし S が共存するとこの上昇は緩和され ることになる。

\section{3 溶 解 性}

図一 5 および表一 2 に燐酸分の溶解率の測定例を示し た. 図一 5 は $\mathrm{N} / 2$ 塩酸に対するもので $\mathrm{R} / \mathrm{P} \fallingdotseq 0.8$ の組 成について, 表一2 は各種の溶媒 (2.3) に対する值で, $\mathrm{R} / \mathrm{P}=1$ についてそれぞれ示したものである.図一5 よ

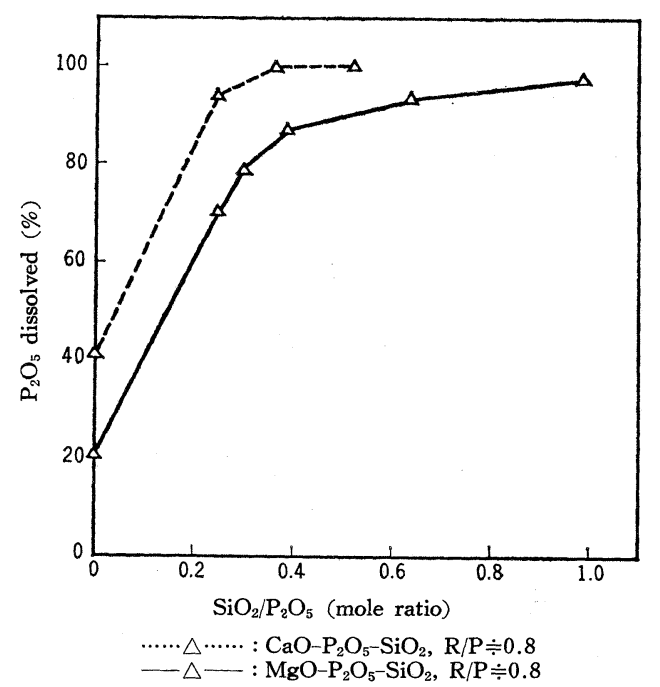

Fig. 5. $\mathrm{P}_{2} \mathrm{O}_{5}$ solubility in $\mathrm{N} / 2 \mathrm{HCl}$.

Table 2. $\mathrm{P}_{2} \mathrm{O}_{5}$ solubilities of $\mathrm{RO}-\mathrm{P}_{2} \mathrm{O}_{5}-\mathrm{SiO}_{2}$ glasses $(\mathrm{R}=\mathrm{Ca}, \mathrm{Mg})$ with the $\mathrm{RO} / \mathrm{P}_{2} \mathrm{O}_{5}$ mole ratio equal to 1 for various solvents.

\begin{tabular}{|c|c|c|c|c|c|c|c|}
\hline \multirow[b]{2}{*}{ Sample } & \multicolumn{7}{|c|}{$\mathrm{P}_{2} \mathrm{O}_{5}$ solubility $(\%)$ in } \\
\hline & Water & $\mathrm{N} / 2 \mathrm{HCl}$ & $\begin{array}{l}2 \% \text { citric } \\
\text { acid }\end{array}$ & $\begin{array}{l}10 \% \text { neutral } \\
\text { sodium citrate }\end{array}$ & $10 \% \mathrm{NaCl}$ & $10 \% \mathrm{NaOH}$ & $10 \% \mathrm{NH}_{4} \mathrm{OH}$ \\
\hline C 21 & 15.0 & 83.0 & 48.3 & 69.9 & 38.9 & 19.3 & 7.2 \\
\hline C 24 & 2.0 & 59.0 & 9.8 & 44.5 & 12.0 & 34.3 & 1.7 \\
\hline M 21 & 17.4 & 80.8 & 58.0 & 53.5 & 39.8 & 38.7 & 2.9 \\
\hline M 23 & 16.0 & 79.7 & 47.0 & 63.1 & 49.6 & 34.0 & 4.0 \\
\hline M 25 & 1.1 & 15.2 & 2.5 & 7.1 & 5.0 & 60.8 & 1.8 \\
\hline
\end{tabular}


り, 同じ $\mathrm{R} / \mathrm{P}, \mathrm{S} / \mathrm{P}$ 比に抒いて溶解率は C-P-S 系> $\mathrm{M}-\mathrm{P}-\mathrm{S}$ 系であること，および $\mathrm{S} / \mathrm{P}$ 比が大きくなると燐 酸溶解率が増大することがわかる。また表一2 から，珪 酸を導入した C-P-S 系の試料 C 21 および M-P-S 系 の試料 M 21，M 23 は 10\% カセイソーダに対する場 合をのぞいて，C-P 系の試料 C 24 および M-P 系の 試料 M 25 にくらべ，それぞれ一般に大きい溶解率をも っていることがみとめられる。これらの系のガラスは全 般的に種々の溶媒に対して非常に大きい溶解率をもって おり，、わゆる化学的耐久性はきわめて低いといってよ い.たとえば水に対する值はいずれも $15 \%$ 以上であり， 非常に大きい.

燐酸イオンの溶解は，その鎖長が小さいほど早いと考 えられる場合が多い。したがって珪酸の添加による溶解 率の増大は, ガラス構造中への S の導入が燐酸イオン の鎖長を小さくする効果をもたらしたことを推定させ る.ただしこの際 $\mathrm{P}-\mathrm{O}-\mathrm{Si}$ 結合が溶解によって切断され るとみなすべきであろう． $\mathrm{SiO}_{4}$ はガラス中ではおの抒 の孤立して存在している，と考えられるから，bulkの 溶解に対して，それが大きな障害とはならないとみてよ い. S の含有量が多い場合には, 溶解後珪酸イオンどう しが集合して縮合をおこし, $\mathrm{SiO}_{2}$ ゲルとして不溶解物 となって残留するようになる.

なお，CPS，MPS における $\mathrm{P}-\mathrm{O}-\mathrm{Si}$ 結合の存在につ いては, 赤外吸収スペクトルの測定によっても, これを 傍証することができる．著者ら ${ }^{18)}$ の検討によれば, CPS， MPS では S 含量がふえるにつれて P-O-P 伸縮振動数 が大の方向にずれ，一方 $\mathrm{P}-\mathrm{O}, \mathrm{P}=\mathrm{O}$ 各伸縮振動の波数， 吸収強度はほとんど変らなかった. またわずかの S の 添加によって P-O-P 振動数が大きく変化することが認 められた。この事実は，S が P-O-P 結合のみを選択的 に切断することを暗示する.すなわち $\mathrm{P}-\mathrm{O}-\mathrm{Si}$ 結合の形 成を意味することになると考える.

各溶媒ごとの溶解性の特質に対する解釈としては, 原 則的に既報 表一2 のデータからひろい上げた知見考察の若干を，下 に列举しょら. (1) 溶解性が $\mathrm{CP}>\mathrm{MP}$ である点は, す でに既報で指摘した。この傾向は S の導入によっても 変化しない，S の添加が，両ガラスの構造特質を本質的 には変えないのであろうと考える. (2) CP では S の導 入がクエン酸溶解性を急昇させる．これは後述の $\mathrm{S}$ 成 分自体の作用の他に，クエン酸分の作用しにくい充填度 の高い骨格構造が，S の導入によってかなり変化したた めであることも考えられる. (3) 前記のように $\mathrm{P}-\mathrm{O}-\mathrm{Si}$ 結合がまず切れるとすると，(P-O)イオン部分と $(\mathrm{Si}-\mathrm{O})$ イオン部分とができるはずである. 前者は, 高分子性 (P-O)イオンよりも小形であるから, 比較的, 易溶性あ るいは高溶解速度をもつであろう. またクエン酸分が存
在するばあい $(\mathrm{Si}-\mathrm{O})$ イオンはクエン酸基と可溶性錯体 を形成できる ${ }^{19) \sim 21)}$ そのため全体が溶けやすい状態の ものになるのではなからうか. そうであるとすれば, $\mathrm{CP}$ ガラスでは, 塩酸溶解性よりもクエン酸溶解性の方 が，はるかに S 添加の影響は大きいことが首肯できる。 (4) MPS が CPS にくらべ, カセイソーダ溶解性が大き いのは, 前者が $\mathrm{SiO}_{2}$ との構造類似性が高いことに起因 するとして，把握できるように思われる。このことは， MPの場合4)異なっていない. (5) ただしカセイソーダ 溶解性は，S がある程度入ることによって低下してく る.これは塩酸溶解性の傾向と逆の対応をなしているこ とになる. $\mathrm{NaOH}$ が長鎖イオン部分あるいは巨大イオ ン部分に，上少作用しやすいといらべきであるが，その 点は一般の高珪酸型ガラスに関しても成立つことであ る. (6) 中性クエン酸ナトリウム, 塩化ナトリウムの両溶 鼡の比較では, いずれのガラスもクエン酸塩のほうが溶 解率大を示す.これはクエン酸基自身の溶解作用を表わ していると考える. (7) $2 \%$ クエン酸と 10\% クエン酸ナ トリウムとをくらべると, M 21 を除けば, 溶解性は, クエン酸塩溶剤の方が中性であるにもかかわらず，大き くなっている.これはクエン酸基の作用がかなり強力で あることを示す証左である. (8) C 21，Ｍ 21，M 23 な どの S 含量の大きいガラスでは, クエン酸ナトリウム溶 解性がとくに高い.上述のような $\mathrm{SiO}_{x}$ 一クエン酸間の 錯体形成がおこるので, S が多いために全体が溶けやす くなる傾向を与えるのであるう. (9) 中性液, カセイソ 一ダ液などに対する溶解性の傾向の説明の詳細について は，さらに十分な検討を続行した上で，あらためて報告 したいと考える.

\section{4 ペーパー・クロマトグラフィー}

図一6〜8 にペーパー・クロマトグラムを示した. 図一 6 より， R/P>1 の C-P-S 系では， $\mathrm{S}$ を含有しない C 14 でみとめられたハイポリイオンが， S を加えた C $11, \mathrm{C} 13$ では消失し，分布が短鎖側に移行している ことがわかる.さらにそこで検出されたイオンは，少量 のピロと中間鎖長のもののみであるといら著しい特徽を もつ.この中間のイオンは, 塩基性溶媒で展開した図一 7 より,トリメタおよびテトラメタの環状イオンである ことが確認された．M-P-S 系でも，S の導入により同 じように燐酸イオンの鎖長は小さくなる.そしてこの場 合には，検出された燐酸イオンはオルトとピロのみであ った.

$\mathrm{R} / \mathrm{P}=1$ の場合も図一 8 より $\mathrm{R} / \mathrm{P}>1$ におけると同様 の $\mathrm{S}$ の影響がみられる. 実測の燐酸イオン分布は, 表一 1 に示した R/P 值から $\bar{n}=2 /\{(\mathrm{R} / \mathrm{P})-1\}$ による計算で 求めた理論上の $\bar{n}$ よりも, 短鎖長によっており, 珄酸 が何らかの影響を与えていると考えられる．たとえば， CPS で R/P>1 の C 11, C 13 の R/P 值はそれぞれ 


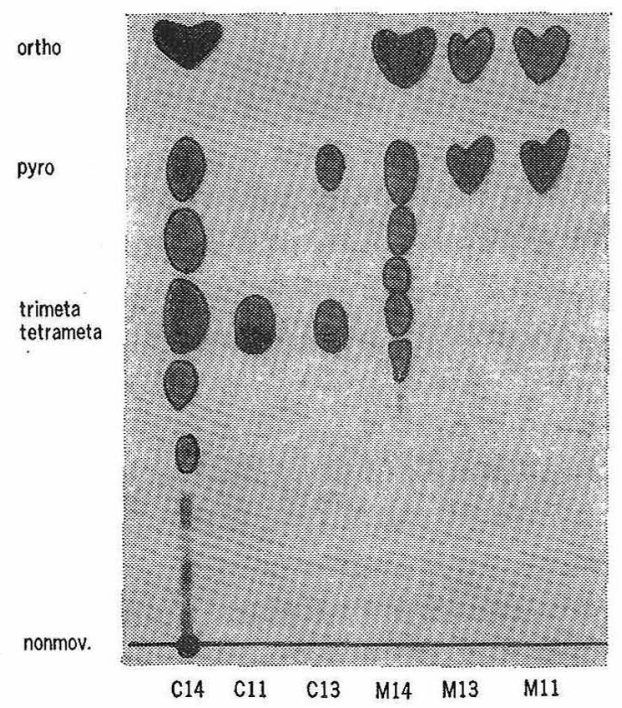

Fig. 6. Paper chromatograms of the glasses in the systems of $\mathrm{CaO}-\mathrm{P}_{2} \mathrm{O}_{5}-\mathrm{SiO}_{2}$ and $\mathrm{MgO}-\mathrm{P}_{2} \mathrm{O}_{5}-\mathrm{SiO}_{2}$ with the $\mathrm{RO} / \mathrm{P}_{2} \mathrm{O}_{5}$ mole ratio larger than 1 , which were developed by acid solvent.

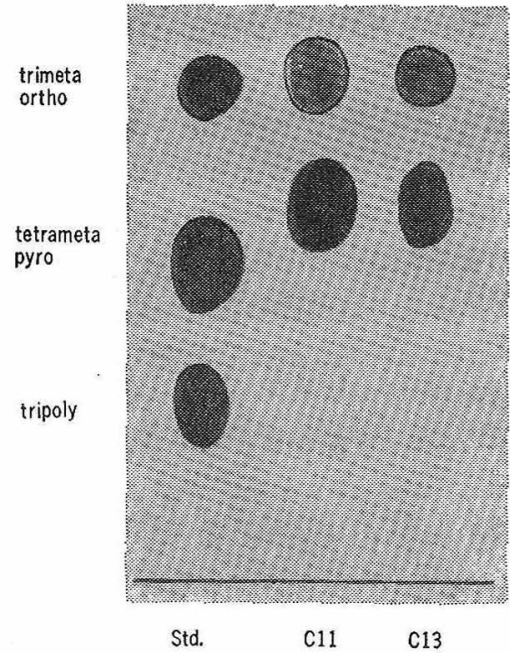

Fig. 7. Paper chromatograms of the $\mathrm{CaO}-\mathrm{P}_{2} \mathrm{O}_{5}-\mathrm{SiO}_{2}$ glasses with the $\mathrm{CaO} / \mathrm{P}_{2} \mathrm{O}_{3}$ mole ratio larger than 1 , which were developed by basic solvent.

$1.20 ， 1.27$ であり，これより求めた $\bar{n}$ はそれぞれ 10 , 7.2 となった. 同様に MPS の M 11, M 13 では R/P がともに 1.66 で $\bar{n}=3$ となった。一方これらの試料中 の燐酸イオンの形態は図一6にみられると括りであっ て，計算で得られるものよりも鎖長がいずれる小さい值 となっている.

$\mathrm{S}$ が (アルカリ土類一橉酸イオン) 部分と反応して, 燐酸イオン鎖を小さくしている様式の細部についてはま だ判断できない部分が多いが，大筋としては，3.2 で述 べたような R と P との反応が優先することおよび $\mathrm{S}$ 添加による粘性の増大などを考慮すると，結果として

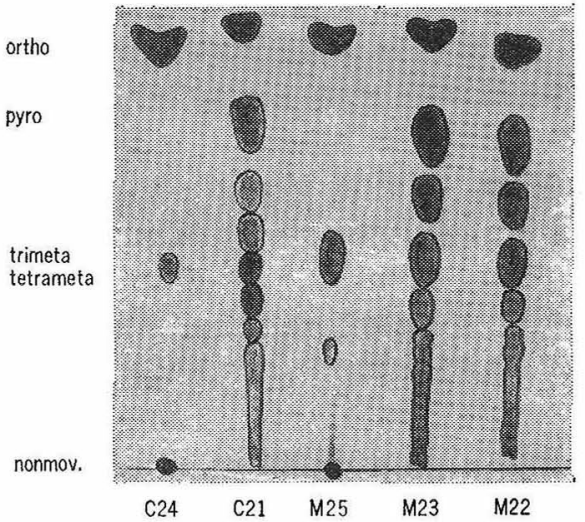

Fig. 8. Paper chromatograms of the glasses in the systems of $\mathrm{CaO}-\mathrm{P}_{2} \mathrm{O}_{5}-\mathrm{SiO}_{2}$ and $\mathrm{MgO}-\mathrm{P}_{2} \mathrm{O}_{5}-\mathrm{SiO}_{2}$ with the $\mathrm{RO} / \mathrm{P}_{2} \mathrm{O}_{5}$ mole ratio equal to 1 , which were developed by acid solvent.

‥O-P-O-Si-O-P-O-P-O $\cdots$ のような結合部分が生成 し，これが，ETA 溶液処理のばあい $\mathrm{Si}-\mathrm{O}$ の部分から 切れて溶解するものと思われる．したがって導入された $\mathrm{S}$ は，ガラス構造の主体をなしている燐酸塩鎖全般にわ たって，ほぼ均一に分布するために，縮合珪酸イオンの よらな大きな anionic group を形成することはないと 考えられる。

$\mathrm{R} / \mathrm{P}>1$ の CPS 試料では, その憐酸イオンの形態が 大部分環状であった事実は，本系のみにみとめられた現 象である. S を含まない $\mathrm{CP}, \mathrm{MP}$ でもこの傾向は多少 みとめられ，環状イオンのタが中間のイオンとして検出 されることもある゙．Ｓの導入により，この性質が助長 されるとも考えられるが, その機構などの詳細は今後の 課題として扱いたい.

\section{5 失透物の $\mathrm{X}$ 線回折}

図一9〜11 は熱処理によって失透させた試料の X 線 回折図である. 加熱条件と生成結晶の種類を表一3にま とめた．図一9，10 は，それぞれ CPS の R/P > 1 お よび $\mathrm{R} / \mathrm{P}=1$ の場合を示し, 図一11 は MPS の回折図 である.これらの図表より，一般的傾向として次の $2 つ$ の事実がみとめられた。

第 1 k, CPS, MPS とも S の量によって, 同じ R/P 比でも異なった燐酸塩結晶の生成がみられることがあ る.たとえば， R/P >1 の CPS では， $\mathrm{S}$ を含まない場 合にはトレメライトが生成しているが，これに珪酸を加 えるとより短鎖燐酸イオンを含む結晶に移行し，ピ口塩 が得られる。さらに，C $35, M 26$ のよ5に $\mathrm{R} / \mathrm{P} \leqq 1$ で あっても， S/P 比が大きくなるとピ口塩が検出されるこ ともある。

第 2 の特徽としては， R/P $<1$ で多量に $\mathrm{S}$ が入って いる場合 $(\mathrm{S} / \mathrm{P}=1)$ をも含めて, 珪酸自体あるいは珄酸 分を含んだ結晶の生成が見られないことがあげられる。 そのほか $\mathrm{R} / \mathrm{P}<1$ の MPS ガラスは失透しにくく， 


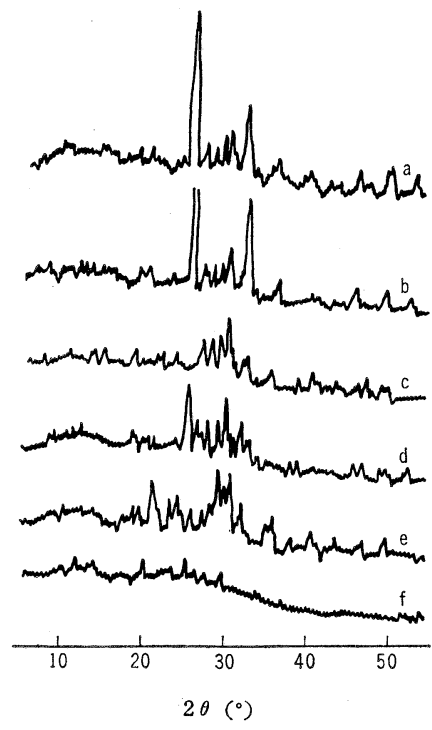

a : C 11 heat-treated at $800^{\circ} \mathrm{C}$ for 1 hour b : C $11 \quad 700^{\circ} \mathrm{C}$ for 15 hour c : C $13 \quad 800^{\circ} \mathrm{C}$ for 1 hour $\mathrm{d}: \mathrm{C} 13 \quad 700^{\circ} \mathrm{C}$ for 15 hours e : C $14 \quad 800^{\circ} \mathrm{C}$ for 1 hour f : C 12 devitrified by air quenching

Fig. 9. X-ray diffraction patterns (No. 1).

表一3 に示した条件では結晶生成がみとめられなかっ た.

つぎにペーパー・クロマトグラフィーより得られたガ ラスの燐酸イオン形態と, $\mathrm{X}$ 線判定による生成結晶中の それをを比較してみる. まず R/P >1 の MPS ではぺ 一パー・クロマトグラムよりオルトとピロ各イオンが検 出され, 一方生成結晶はピロ燐酸マグネシウムであり，
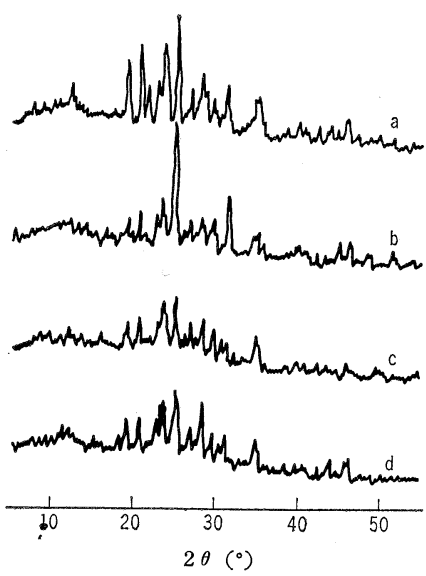

a : C 2 heat-treated at $800^{\circ} \mathrm{C}$ for 1 hour b : C 21 " $700^{\circ} \mathrm{C}$ for 15 hours c : C 33 " $750^{\circ} \mathrm{C}$ for 1 hour

$\mathrm{d}: \mathrm{C} 33 \quad 650^{\circ} \mathrm{C}$ for 15 hours

Fig. 10. X-ray diffraction patterns (No. 2).

比較的よい対応を示している. CPS ではペーパー・ク ロマトグラムおよび $\mathrm{X}$ 線回折パターンにおいて共通に みとめられているピ口塩以外に，ガラスのペーパー・ク ロマトグラムではトリメタ，テトラメタ各イオンが，X 線分析では失透生成物中にメ夕燐酸塩がそれぞれ検出さ れている. 形式上環状イオンが開環重合して結晶化した ようにみえるが，この点の解釈についてはまだ不明であ る. $\mathrm{R} / \mathrm{P}=1$ においてはペーパー・クロマトグラフィー によるイオンの分布は広い範囲にひろがっているので， 必らずしも断定しがたいけれども，ポリ燐酸塩が生成す るものと考えられる. したがって 3.4 と 3.5 に述べた

Table 3. Crystalline substances formed by heattreatment of the glasses in the system $\mathrm{RO}-\mathrm{P}_{2} \mathrm{O}_{5}-\mathrm{SiO}_{2}(\mathrm{R}=\mathrm{Ca}, \mathrm{Mg})$

\begin{tabular}{|c|c|c|c|c|c|c|}
\hline \multirow{2}{*}{ Sample } & \multicolumn{2}{|c|}{ Condition of heating } & \multirow{2}{*}{ Crystalline substances identified } & \multicolumn{2}{|c|}{ Condition of heating } & \multirow{2}{*}{ Crystalline substances identified } \\
\hline & temperature $\left({ }^{\circ} \mathrm{C}\right)$ & time $(\mathrm{hr})$ & & temperature $\left({ }^{\circ} \mathrm{C}\right)$ & time $(\mathrm{hr})$ & \\
\hline C 11 & 700 & 15 & $\beta-\mathrm{C}_{2} \mathrm{P}^{\mathrm{a})}, \delta-\mathrm{CP}^{\mathrm{b})}$ & 800 & 1 & $\beta-\mathrm{C}_{2} \mathrm{P}, \beta-\mathrm{CP}^{\mathrm{c})}$ \\
\hline C 12 & air quench & & $\beta-\mathrm{C}_{2} \mathrm{P}$ & & & \\
\hline C 13 & 700 & 15 & $\beta-\mathrm{C}_{2} \mathrm{P}, \delta-\mathrm{CP}$ & " & " & $\beta-\mathrm{C}_{2} \mathrm{P}, \delta-\mathrm{CP}$ \\
\hline C 14 & " & " & trömelite & " & " & trömelite \\
\hline C 21 & 750 & " & $\delta-\mathrm{CP}, \beta-\mathrm{CP}$ & $"$ & $"$ & $\beta-\mathrm{CP}$ \\
\hline C 22 & 650 & $"$ & $\beta-\mathrm{CP}, \beta-\mathrm{C}_{2} \mathrm{P}$ & 750 & " & $\delta-\mathrm{CP}$ \\
\hline C 23 & $"$ & " & $", "$ & $"$ & $"$ & $\beta-\mathrm{CP}, \beta-\mathrm{C}_{2} \mathrm{P}$ \\
\hline C 24 & $"$ & " & $\beta-\mathrm{CP}$ & " & $"$ & $\beta-\mathrm{CP}$ \\
\hline C 31 & " & " & & $"$ & $"$ & $\Rightarrow$ \\
\hline C 32 & " & " & $\beta-\mathrm{CP}, \beta-\mathrm{C}_{2} \mathrm{P}$ & " & $"$ & $\beta-\mathrm{CP}, \beta-\mathrm{C}_{2} \mathrm{P}$ \\
\hline C 33 & $"$ & $"$ & $\beta-\mathrm{CP}$ & $"$ & $"$ & $\beta-\mathrm{CP}$ \\
\hline C 34 & $"$ & $"$ & $"$ & $"$ & $"$ & " \\
\hline M 11 & 700 & $"$ & $\mathrm{M}_{2} \mathrm{P}^{\mathrm{d})}$ & 800 & $"$ & $\mathrm{M}_{2} \mathrm{P}$ \\
\hline M 12 & $"$ & $"$ & $"$ & " & $"$ & $\mathrm{M}_{2} \mathrm{P}, \mathrm{MP}$ \\
\hline M 13 & $\Rightarrow$ & $"$ & 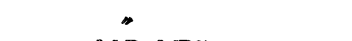 & " & " & $\mathrm{M}_{2} \mathrm{P}$ \\
\hline M 14 & $"$ & $\Rightarrow$ & $\mathrm{M}_{2} \mathrm{P}, \mathrm{MP}^{\mathrm{e})}$ & & & \\
\hline M 22 & 800 & 1 & & & & \\
\hline M 24 & $"$ & $"$ & $\mathrm{MP}, \mathrm{M}_{2} \mathrm{P}$ & & & \\
\hline M 25 & $"$ & $"$ & MP & & & \\
\hline M 32 & 750 & $"$ & $"$ & & & \\
\hline M 33 & $"$ & $"$ & & & & \\
\hline M 34 & $"$ & " & & & & \\
\hline
\end{tabular}

a) $\beta-\mathrm{C}_{2} \mathrm{P}: \beta$-calcium pyrophosphate, b) $\delta$-CP: $\delta$-calcium metaphosphate, c) $\beta$-CP : $\beta$-calcium metaphosphate,

d) $\mathrm{M}_{2} \mathrm{P}$ : magnesium pyrophosphate, e) $\mathrm{MP}:$ magnesium metaphosphate 


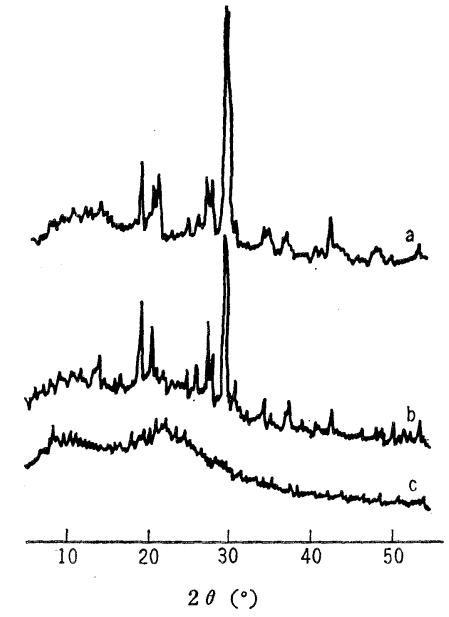

a : M 14 heat-treated at $800^{\circ} \mathrm{C}$ for 1 hour b : M 24 c : $\mathrm{M} 33$

Fig. 11. X-ray diffraction patterns (No. 3).

知見どうしはかなり良く一致しており，それらの結果は 珪酸と燐酸イオン鎖との反応のひとつの証左となりらる ものであろう.このことは同時に，ガラスの溶解の場合 と同じように，結晶化のさいにも O-P-O-Si-O-P-O 結 合の分解が生じていることを示すと考えられる。

珪酸結晶の生成がみられないことは，燐酸鎖との反応 の結果, $\mathrm{Si}$ 原子は燐酸イオン鎖中に 1 個ずつ引き離さ れた状態 となるので, $\mathrm{SiO}_{2}$ として析出するためにはス ケールの大きな拡散を必要とし，それはかなり困難であ ることを推測させる。

珄酸分を含む結晶もやはり見出されないことがわかっ たが，むしもそれが生成したと仮定すれば，この場合 $\mathrm{R}$ の珪酸塩または珪燐酸塩のいずれかになるはずである. 前者はアルカリ土類一燐酸間の反応が優先的であるとい ら前提からして, 生成しないものと判断される. また後 者の問題については，つぎのことがいえる．

珪酸と燐酸との間に成立する物質としては, 種々の結 晶形の $\mathrm{SiP}_{2} \mathrm{O}_{7}$ のほか $3 \mathrm{SiO}_{2} \cdot 2 \mathrm{P}_{2} \mathrm{O}_{5}$ および $2 \mathrm{SiO}_{2}$. $\mathrm{P}_{2} \mathrm{O}_{5}$ などの存在が指摘 ${ }^{22)}{ }^{23)}$ されている. これらの $\mathrm{S} / \mathrm{P}$ 比はそれぞれ $1,1.5,2$ である. 本試料では, 最も多量 に $\mathrm{S}$ を含んだ場合でも $\mathrm{S} / \mathrm{P}=1$ で，このとき $\mathrm{SiP}_{2} \mathrm{O}_{7}$ の それにひとしい.しかし今の場合は同時に $\mathrm{M}$ が共存し ているため, 燐酸は珠燐酸塩結晶を生成するよりも，燐 酸マグネシウム塩として結晶化する方が容易であるう. したがって組成上，珪燐酸塩結晶の生成の可能性も，こ の場合は小さいと考えられる.

\section{4. 総括}

$\mathrm{CaO}-\mathrm{P}_{2} \mathrm{O}_{5}-\mathrm{SiO}_{2}$ 系抒よび $\mathrm{MgO}-\mathrm{P}_{2} \mathrm{O}_{5}-\mathrm{SiO}_{2}$ 系の各ガ ラスについて, ガラス化領域, 密度・屈折率, 燐酸溶解 性，燐酸イオンの鎖長，加熱生成物の鉱物組成などを測
定検討した. 主な知見を次に要約する.

1) $\mathrm{MgO}-\mathrm{P}_{2} \mathrm{O}_{5}-\mathrm{SiO}_{2}$ 系は $\mathrm{CaO}-\mathrm{P}_{2} \mathrm{O}_{5}-\mathrm{SiO}_{2}$ 系より一 般に広いガラス化領域を有する。

2）珪酸含量を多くすると, 密度・屈折率は減少す る.また $\mathrm{MgO}-\mathrm{P}_{2} \mathrm{O}_{5}-\mathrm{SiO}_{2}$ 系においても， $\mathrm{MgO}-\mathrm{P}_{2} \mathrm{O}_{5}$ 系に扮けると同様な物性の anomaly が， $\mathrm{MgO} / \mathrm{P}_{2} \mathrm{O}_{5}$ 干 ル比1付近においてみとめられる。

3) $\mathrm{CaO}-\mathrm{P}_{2} \mathrm{O}_{5}$ 系および $\mathrm{MgO}-\mathrm{P}_{2} \mathrm{O}_{5}$ 系と比較して, 種々の溶媒, とくに酸性溶媒に対する溶解性が, 本系ガ ラスでは非常に大きい.

4) $\mathrm{CaO} / \mathrm{P}_{2} \mathrm{O}_{5}$ モル比 1 がより大きい $\mathrm{CaO}-\mathrm{P}_{2} \mathrm{O}_{5}-\mathrm{SiO}_{2}$ 系ガラスでは，ガラス中の燐酸イオンの形態は，ほとん ど環状のトリメタおよびテトラメタである.

5）これらの系のガラスを熱処理して失透させたとき に生じる結晶は，いずれも燐酸塩のみであって，珠酸， 珪酸塩および珪燐酸塩は生成しない。

本報の内容は昭和 41 年 3 月 31 日, 日本化学会第 19 年会で講 演した [講演番号 $2 \mathrm{~J} 018$ ]

\section{文献}

1）金沢孝文，窝協 72，27 (1964).

2）金沢孝文，池田正義，工化 70，115 (1967).

3）金沢孝文, 中井 章, 川副博司, 工化 72，2211 (1969)。

4）金沢孝文，池田正義，川副博司，䈍協 71，163 (1969).

5) E. Kordes, W. Vogel, and R. Feterowsky, Z. Elektrochem. 57, 282 (1953).

6) D.J. du Plessis, Angerw. Chem. 71, 697 (1959).

7) K. Takahashi, "Advances in Glass Technology" Technical Papers of the VI th I.C.G. 366 (1962).

8) S. Ohashi and F. Oshima, Bull. Chem. Soc. Japan, 36, 1489 (1963).

9) U. Sedmalis, R. Berzins, and B. Hofmanis, Latvijas PSR Zinatnu Akad. Vestis, Kim. Ser. 1962, 341; Chem. Abst. 59, 292 h (1963).

10) U. Sedmalis, R. Berzins, and B. Hofmanis, ibid. 1962, 349; Chem. Abst. 58, 12265 h (1963).

11）中村輝雄（監修), “肥料分析法”養賢堂 (1962) p. 77.

12）文献 11)の p. 130 预よび p. 145.

13) 文献 11)の p. 116.

14) D.N. Bernhart and W.B. Chess, Anal. Chem. 31, 1026 (1959).

15) J.P. Ebel and Y. Volmer, Compt. rend. 233, 415 (1951).

16) C.A. Elyard, P.L. Baynton, and H. Rawson, Glastech. Ber. Sonderband 32 K, VI 36 (1959).

17）成瀬 省, 阿部良弘, 井上博義, 㸃協 76, 36 (1968).

18）金沢孝文, 池田正義, 川副博司，日化第 20 年会講演予稿 集 II , p. 579 (1967).

19）金沢孝文，酒井清次，日化第 15 年会講演要旨集 p. 372 (1962).

20）金沢孝文，加藤友昭，日化第 17 年会講演要旨集 p. 35 (1964).

21）金沢孝文，石高石灰研究会第 27 回学術講演会講演要旨集 p. 3 (1963).

22) F. Liebau and G. Bissert, Bull. soc. chim. France, Colloque international sur les phosphates minéraux solides, 1742 (1968).

23) F. Liebau, G. Bissert, and N. Köppen, Z. anorg. allgem. Chem. 359, 113 (1968).

(6/6/1969 受付) 